HELMINTHOLOGIA, 55, 2: 95 - 101, 2018

\title{
New data on the morphology and phylogenetic connections of Postlepidapedon opisthobifurcatum (Trematoda, Lepocreadioidea: Lepidapedidae), a parasite of Antarctic and sub-Antarctic fishes
}

\author{
S. G. SOKOLOV', F. K. KHASANOV', I. I. GORDEEV2,3,*
}

${ }^{1}$ Center of Parasitology, A.N. Severtsov Institute of Ecology and Evolution RAS, Leninskij prospect, 33, Moscow, 119071, Russia; 2Lomonosov Moscow State University, Leninskie Gory, 1, Moscow, 119234, Russia, ${ }^{*}$ E-mail: gordeev_ilya@bk.ru; ${ }^{3}$ Russian Federal Research Institute of Fisheries and Oceanography, V. Krasnoselskaya Str., 17, Moscow, 107140, Russia

Article info

Received August 28, 2017 Accepted January 17, 2018

\begin{abstract}
Summary
The trematode Postlepidapedon opisthobifurcatum (Zdzitowiecki, 1990) is a common intestinal parasite of the gadiform fishes of the Southern Ocean. In this work, we supplement the description of the species with the anatomy of the terminal part of the reproductive system and with molecular data. The male terminal genitalia are characterised by the presence of the external seminal vesicle and cirrus-sac. The external seminal vesicle is surrounded by aciniform groups of outer prostatic cells. Groups of outer prostatic cells and proximal parts of their ducts are associated with a thin-walled membrane that is connected to the proximal edge of the cirrus-sac. The cirrus-sac is claviform, with a long proximal part accommodating the tubular, thin-walled internal seminal vesicle and ducts of outer prostatic cells. The female terminal genitalia are represented by a thick-walled metraterm, which is surrounded by aciniform groups of glandular cells. Phylogenetic analysis based on $28 \mathrm{~S}$ rDNA partial sequences data placed $P$. opisthobifurcatum into the monophyletic group Lepidapedidae, including the species Myzoxenus insolens (Crowcroft, 1945), Intusatrium robustum Durio et Manter, 1968, and Postlepidapedon uberis Bray, Cribb et Barker, 1997. However, we were unable to detect direct phylogenetic connections between $P$. opisthobifurcatum and $P$. uberis.
\end{abstract}

Keywords: Trematoda; Postlepidapedon opisthobifurcatum; Lepidapedidae

\section{Introduction}

The trematode Postlepidapedon opisthobifurcatum (Zdzitowiecki, 1990) Zdzitowiecki, 1993 is one of the common intestinal parasites of Antarctic and sub-Antarctic fishes of the families Muraenolepididae and Macrouridae (Zdzitowiecki, 1990; Zdzitowiecki \& Cielecka, 1997; Walter et al., 2002; Sokolov \& Gordeev, 2013; 2015; Gordeev \& Sokolov, 2017). This species was originally included in the genus Neolepidapedon Manter, 1954 (see Zdzitowiecki, 1990). Zdzitowiecki (1993) subsequently erected a new genus, Postlepidapedon, based on the morphology of the cirrus-sac (presence of elongated, thin-walled internal seminal vesicle and narrow, long ejaculatory duct), the position of the intestinal bifurcation, and a number of other characters to accommodate Neolepidapedon opisthobifurcatus Zdzitowiecki, 1990. Other than the type species ( $P$. opisthobifurcatum), this genus currently includes five other congeners, described from perciform fishes from the waters off Australia, New Caledonia, and the Philippines (Bray et al., 1997; Bray \& Cribb, 2001; Machida, 2004). Bray \& Cribb (2012) placed the genus Postlepidapedon into the family Lepidapedidae.

The aim of the present study is to describe in more detail the morphology of the terminal part of reproductive system of adult $P$. opisthobifurcatum and to define the phylogenetic position of this species based on molecular data.

\footnotetext{
$\bar{*}$ - corresponding author
} 


\section{Materials and Methods}

\section{Specimen collection and morphological study}

The digeneans were collected during parasitological examination of specimens of Muraenolepis marmorata Günther, 1880 (Gadiformes, Muraenolepididae) caught on 18 March 2013 in the central part of the Ross Sea $\left(75^{\circ} 48 \mathrm{~S} 172^{\circ} 48 \mathrm{~W}\right)$. All hosts (length 49 - $55 \mathrm{~cm}$, weight $0.9-1.4 \mathrm{~kg}$ ) were caught by the fishing vessel Yantar-35 while it was fishing for the toothfish Dissostichus spp. at depths ranging from $962 \mathrm{~m}$ to $1228 \mathrm{~m}$ using bottom longline fishing gear (autoline) "Mustad" (Petrov et al., 2014) inside the Convention for the Conservation of Marine Living Resources (CCAMLR) area. The worms collected for morphological study were fixed in $70 \%$ ethanol under a cover glass without additional pressure and stained with acetocarmine. Trematode species were identified using the publications of Zdzitowiecki (1990; 1993) and Zdzitowiecki \& Cielecka (1997). The drawing and dimensions of $P$. opisthobifurcatum from our collection are given in Sokolov \& Gordeev (2013).

The description of the terminal part of the reproductive system is based on the study of isolated organs (from 20 specimens) extracted from the bodies using needles. The worms used in the phylogenetic analysis were fixed in $95 \%$ ethanol. Voucher specimens of the studied species were deposited in the Museum of Helminthological Collections, Centre for Parasitology, A.N. Severtsov Institute of Ecology and Evolution, Russian Academy of Sciences, Moscow, Russia (IPEE RAS).

DNA extraction, amplification, sequencing, and phylogenetic analysis

Genomic DNA was extracted from single specimens of adult worms following the protocol used by Tkach et al. (1999). Nuclear 28S rDNA partial fragment, including D1-D3 domains, was amplified using a polymerase chain reaction by the following primers: DIG12 (5'- AAG CAT ATC ACT AAG CGG-3') and 1500R (5'- GCT ATC CTG AGG GAAACT TCG-3') (Tkach et al., 2003). The initial polymerase chain reaction was carried out in a total volume of $25 \mu$ l containing $0.25 \mathrm{mM}$ of each primer pair, $5 \mu$ l DNA in water, 1× Phusion polymerase buffer, $2.5 \mathrm{mM}$ dNTP, and 1 unit of Phusion High-Fidelity DNA Polymerase (New England Biolabs, UK). The amplification of a 1330-bp fragment of 28S rDNA was performed in a GeneAmp 9700 (Applied Biosystems) with a 1-min denaturation hold at $95^{\circ} \mathrm{C} ; 30$ cycles of $30 \mathrm{~s}$ at $95^{\circ} \mathrm{C}, 30 \mathrm{~s}$ at $55^{\circ} \mathrm{C}$, and $60 \mathrm{~s}$ at $72{ }^{\circ} \mathrm{C}$; followed by a 2 -min extension hold at $72^{\circ} \mathrm{C}$. Negative and positive controls, using both primers, were used. The PCR products were directly sequenced using an ABI Big Dye Terminator v.3.1 Cycle Sequencing Kit, as recommended by the manufacturer, with the internal sequencing primers $300 \mathrm{~F}\left(5^{\prime}-\mathrm{CAA}\right.$ GTA CCG TGA GGG AAA GTT G-3') , ECD2 (5'-CTT GGT CCG TGT TTC AAG ACG GG-3'), 900F (5'-CCG TCT TGA AAC ACG GAC CAA G-3'), and 1200R (Tkach et al., 2003). The sequences obtained have been submitted to NCBI GenBank (Table 1).
Phylogenetic relationships were performed using our data and nucleotide sequences of $28 \mathrm{~S}$ rDNA of lepidapedids from the NCBI GenBank database (Table 1). Due to the limited data on trematodes of the family Lepidapedidae deposited in the GenBank, we also used an original sequence of Muraenolepitrema magnatestis Gaevskaya et Rodjuk, 1988 collected from the same host and in the same region as $P$. opisthobifurcatum (see above, and Sokolov \& Gordeev, 2015). Representatives of the families Enenteridae and Gyliauchenidae (Table 1) were selected as the outgroup based on their phylogenetic position relative to the family Lepidapedidae (see Bray \& Cribb, 2012). Most of the 28S rDNA sequences of lepidapedids deposited into NCBI GenBank database are about $900 \mathrm{bp}$ long. In this regard, two variants of the tree are given in this paper. The first is built based on $900 \mathrm{bp}$, and includes the maximum number of species of the Lepidapedidae deposited in GenBank. The second one is built with 1230 bp alignment length and includes a limited number of species. Initially, the sequences were aligned with the aid of ClustalX using default parameters (Jeanmougin et al., 1998), and then they were refined by estimating the number of variable sites and sequence differences using MEGA 6.0 (Tamura et al., 2013). Phylogenetic analysis of the nucleotide sequences was performed using Bayesian inference implemented in MrBayes v.3.2.6 on CIPRES portal (Miller et al., 2010). The analysis was conducted using the GTR+I+G model, where ngen was set to $5 \times 10^{6}$, with two runs each containing four simultaneous Markov ChainMonte Carlo (MCMC) chains and every $10000^{\text {th }}$ tree saved. An evolutionary model for the Bayesian inference analysis was selected using MEGA v.7.0.21 (Kumar et al., 2016). Samples of substitution model parameters and tree and branch lengths were summarised using the parameters "sump burnin $=0.25$ " and "sumt burnin $=0.25$ ". The significance of the phylogenetic relationships was estimated by posterior probabilities (Huelsenbeck et al., 2001).

\section{Ethical Approval and/or Informed Consent}

The conducted research is not related to either human or animals use. Informed consent has been obtained from all individuals included in this study.

\section{Results}

Morphology of the terminal part of the reproductive system

The male terminal genitalia are represented by the external seminal vesicle, cirrus-sac, and complex of outer prostatic cells (Fig. 1). The vas deferens is absent; vasa efferentia is joined directly to the external seminal vesicle. The external seminal vesicle is large, 1.5 - 2 times longer than the cirrus-sac, convoluted, and surrounded by aciniform groups of outer prostatic cells radiating into the parenchyma. Groups of outer prostatic cells and proximal parts of their ducts are covered with a thin-walled open-ended membrane. The membrane is divided into two sheets - dorsal and ventral. 
Table 1. List of taxa, incorporated into molecular analysis.

\begin{tabular}{lccc}
\hline Species & Family & Reference & $\begin{array}{c}\text { GenBank } \\
\text { accession number }\end{array}$ \\
\hline Bulbocirrus aulostomi Yamaguti, 1965 & & Bray et al. (2009) & FJ788470 \\
Intusatrium robustum Durio et Manter, 1968 & Lepidapedidae & Bray et al. (2009) & FJ788481 \\
Lepidapedon arlenae Bray et Gibson, 1995 & Lepidapedidae & Bray et al. (1999) & AJ405262 \\
Lepidapedon beveridgei Campbell et Bray, 1993 & Lepidapedidae & Bray et al. (1999) & AJ405263 \\
Lepidapedon desclersae Bray et Gibson, 1995 & Lepidapedidae & Bray et al. (1999) & AJ405264 \\
Lepidapedon discoveryi Bray et Gibson, 1995 & Lepidapedidae & Bray et al. (1999) & AJ405265 \\
Lepidapedon elongatum (Lebour, 1908) & Lepidapedidae & Bray et al. (1999) & AJ405266 \\
Lepidapedon gaevskayae Campbell et Bray, 1993 & Lepidapedidae & Bray et al. (1999) & AJ405267 \\
Lepidapedon rachion (Cobbold, 1858) & Lepidapedidae & Bray et al. (1999) & AJ405261 \\
Lepidapedon sommervillae Bray et Gibson, 1995 & Lepidapedidae & Bray et al. (1999) & AJ405268 \\
Lepidapedon zubchenkoi Campbell et Bray, 1993 & Lepidapedidae & Bray et al. (1999) & AJ405269 \\
Muraenolepitrema magnatestis Gaevskaya et Rodjuk, 1988 & Lepidapedidae & This study & KY497958 \\
Myzoxenus insolens (Crowcroft, 1945) & Lepidapedidae & Bray et al. (2009) & FJ788486 \\
Neolepidapedon smithi Bray et Gibson, 1989 & Lepidapedidae & Bray et al. (1999) & AJ405270 \\
Postlepidapedon opisthobifurcatum (Zdzitowiecki, 1990) & Lepidapedidae & This study & KY497957 \\
Postlepidapedon uberis Bray, Cribb et Barker, 1997 & Lepidapedidae & Bray et al. (2009) & FJ788492 \\
Profundivermis intercalarius Bray et Gibson, 1991 & Lepidapedidae & Bray et al. (1999) & AJ405271 \\
\hline Outgroup & & & \\
Koseiria xishaense Gu et Shen, 1983 & Enenteridae & Olson et al. (2003) & AY222233 \\
Petalocotyle adenometra Hall et Cribb, 2000 & Gyliauchenidae & Bray et al. (2009) & FJ788504 \\
\hline
\end{tabular}

Distal ends of the membrane's sheets are connected to the proximal edge of the cirrus-sac. The cirrus-sac is $0.237-0.331 \mathrm{~mm}$ long and $0.05-0.06 \mathrm{~mm}$ maximal wide, and it is composed of internal seminal vesicle, pars prostatica, ejaculatory duct and eversible cirrus. The cirrus-sac is claviform, with a long proximal part accommodating the proximal part of the internal seminal vesicle and numerous ducts of the outer prostatic cells. The internal seminal vesicle is long, $50-70 \%$ the length of the cirrus-sac, tubular, rectilinear or slightly twisted, and thin-walled. The pars prostatica is vesicular. The proximal half of the pars prostatica and distal end of the inner seminal vesicle are surrounded by a field of inner prostatic cells. The cirrus is unarmed and almost cylindrical. The female terminal genitalia are represented by a thick-walled metraterm running over dorsal or dorso-lateral surface of the cirrus-sac, and surrounded by aciniform groups of glandular cells. The length of the metraterm is $0.13-0.15 \mathrm{~mm}$, which represents $40-60 \%$ of the cirrus-sac length. The male and female canals open into the small genital atrium.

\section{Phylogenetic analysis}

Bayesian inference analysis based on sequences containing
900 bp produced topologies in which $P$. opisthobifurcatum formed a strongly supported clade with Myzoxenus insolens (Crowcroft, 1945), within a polytomic clade also composed of Intusatrium robustum Durio et Manter, 1968 and Postlepidapedon uberis Bray, Cribb et Barker, 1997 (Fig. 2a). In turn, the above-mentioned polytomic clade is weakly supported as a sister group to a large clade of lepidapedids, consisting of $M$. magnatestis and two monophyletic clades: Lepidapedon spp. and Neolepidapedon smithi Bray et Gibson, 1989 + Profundivermis intercalarius Bray et Gibson, 1991. The trematode Bulbocirrus aulostomi Yamaguti, 1965 is basal taxa to all other Lepidapedidae.

Bayesian inference analysis based on sequences containing 1230 bp has revealed that $P$. opisthobifurcatum and $M$. insolens formed a clade that was sister to $P$. uberis with low support (Fig. 2b) and in turn this clade composed of three species was sister to I. robustum with high support. The species M. magnatestis and $B$. aulostomi form a strongly supported sister clade to the above-mentioned group of lepidapedids. Postlepidapedon opisthobifurcatum and $P$. uberis were no more closely related than they were to other lepidapedids. 


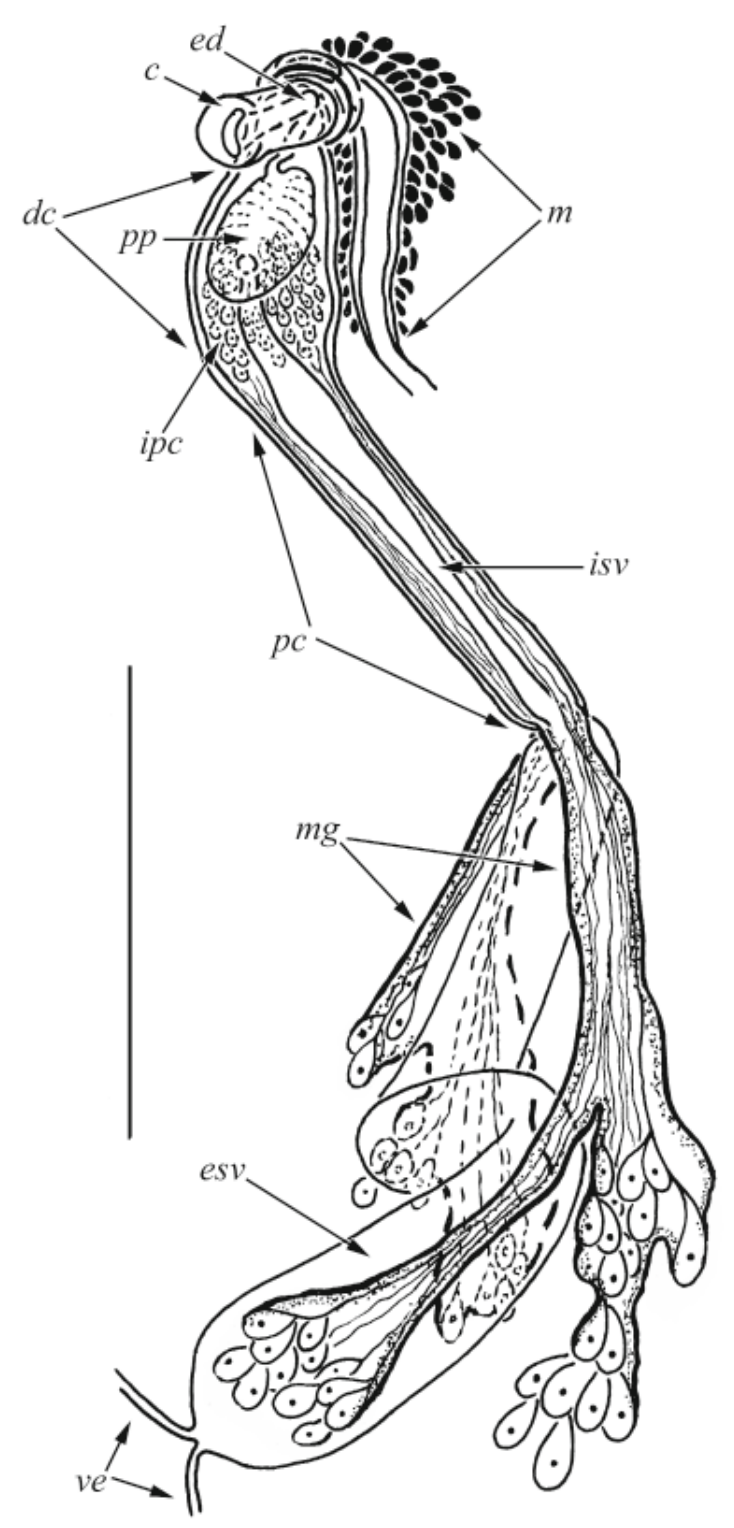

Fig. 1. Male and female terminal genitalia of Postlepidapedon opisthobifurcatum with cirrus everted through genital atrium, ventral view, bar $0.2 \mathrm{~mm}$; $d c$ distal part of cirrus-sac, $p c$ proximal part of cirrus-sac, $c$ cirrus, ed ejaculatory duct, $p p$ pars prostatica, ipc inner prostatic cells, isv internal seminal vesicle, $m g$ outer prostatic cells associated with thin-walled membrane, esv external seminal vesicle, ve vasa efferentia, $m$ metraterm surrounded by glandular cells

\section{Discussion}

According to Zdzitowiecki $(1990,1993)$, the cirrus-sac of $P$. opisthobifurcatum has an elongate-oval or clavate shape and it contains an elongate, but not exceptionally long, thin-walled internal seminal vesicle, a vesicular pars prostatica, a long and narrow ejaculatory duct, and a small cirrus. The external seminal vesicle is long and convoluted, and lies free in the parenchyma.
The outer prostatic cells of $P$. opisthobifurcatum were not found by Zdzitowiecki $(1990,1993)$. However, the proximal edge of the cirrus-sac and the area in which the external seminal vesicle is located are difficult to observe in whole mounts of this parasite, because they are obscured by the ventral sucker, loops of uterus, and vitelline follicles. The study of the isolated terminal part of the reproductive system revealed outer prostatic cells associated with thin-walled open-ended membrane. The membrane, which covers some clusters of outer prostatic cells, is described for other lepidapedids, in particular Paralepidapedon sebastisci (Yamaguti, 1938), M. magnatestis, and also for some opecoelids (Shimazu \& Shimura, 1984; Sokolov \& Gordeev, 2015; Shimazu, 2016). Shimazu \& Shimura (1984) consider it as the rudiment of the wall of the membranous sac (=proximal portion of cirrus-sac by Shimazu \& Shimura's terminology), inherent for many lepidapedids and some opecoelids (see Bray, 2005; Cribb, 2005).

The position of $P$. uberis in the obtained phylograms (Fig. 2), separated from $P$. opisthobifurcatum, is consistent with differences in the morphology of the male terminal genitalia. Postlepidapedon uberis has a subglobular cirrus-sac with a small proximal part, containing a convoluted internal seminal vesicle. The ejaculatory duct is relatively short and thick-walled. The complex of the outer prostatic cells is absent in P. uberis (see Bray \& Cribb, 2001). In addition, this species differs from $P$. opisthobifurcatum in the position of vitelline follicles. In $P$. uberis vitelline follicles form two lateral fields that are arranged in hindbody. These fields overlap the intestinal branches ventrally, laterally and dorsally (Bray \& Cribb, 2001). In $P$. opisthobifurcatum, in addition to the lateral fields arranged in hindbody, there are two longitudinal intercaecal rows of the vitelline follicles that lie on the dorsal side of the body. Lateral fields of vitelline follicles in this species overlap the intestinal branches only ventrally and partly laterally (Zdzitowiecki, 1990).

Four other species of the genus Postlepidapedon: Postlepidapedon philippinense Machida, 2004, Postlepidapedon secundum (Durio et Manter, 1968), Postlepidapedon spissum Bray, Cribb et Barker, 1997, and Postlepidapedon quintum Bray et Cribb, 2001 also differ from $P$. opisthobifurcatum in the shape of the cirrus-sac (oval or elongate-oval without detached proximal part) (Bray et al., 1997; Bray \& Cribb, 2001; Machida, 2004). The species P. philippinense, $P$. secundum, and $P$. quintum do not have a complex of the outer prostatic cells. The distal end of the external seminal vesicle of $P$. spissum is encircled by glandular cells, lying unconfined in the parenchyma. (Bray et al., 1997). Moreover, P. secundum has a coiled thin-walled internal seminal vesicle, while $P$. spissum and $P$. quintum have a rectilinear, but thick-walled, internal seminal vesicle. Postlepidapedon philippinense has rectilinear thin-walled internal seminal vesicle (Machida, 2004). The placement of lateral fields of the vitellarium relative to the intestinal branches in $P$. quintum $P$. secundum, and $P$. spissum is the same as in $P$. uberis (Bray et al., 1997; Bray \& Cribb, 2001). Accurate information about mutual location of lateral fields and intestinal branches in $P$. philippinense is absent (see Machida, 2004). We think it is likely that 


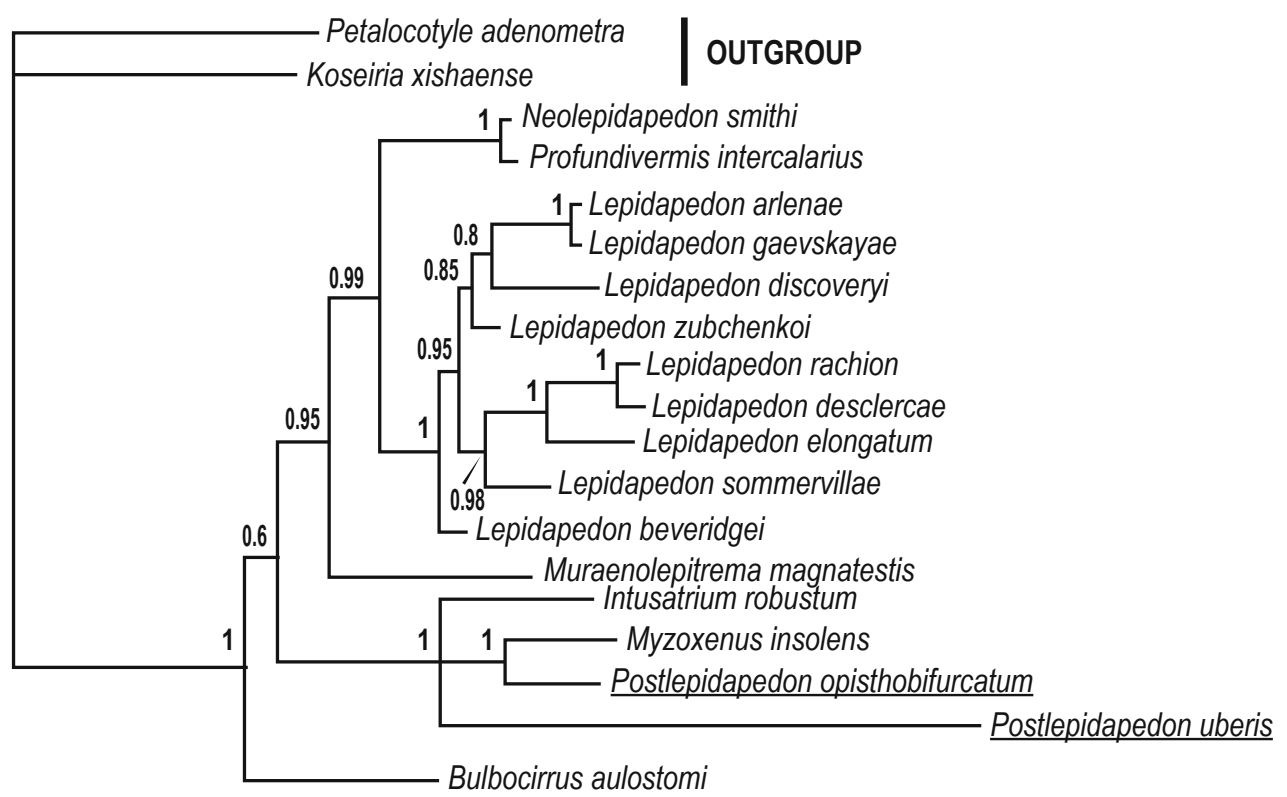

Petalocotyle adenometra

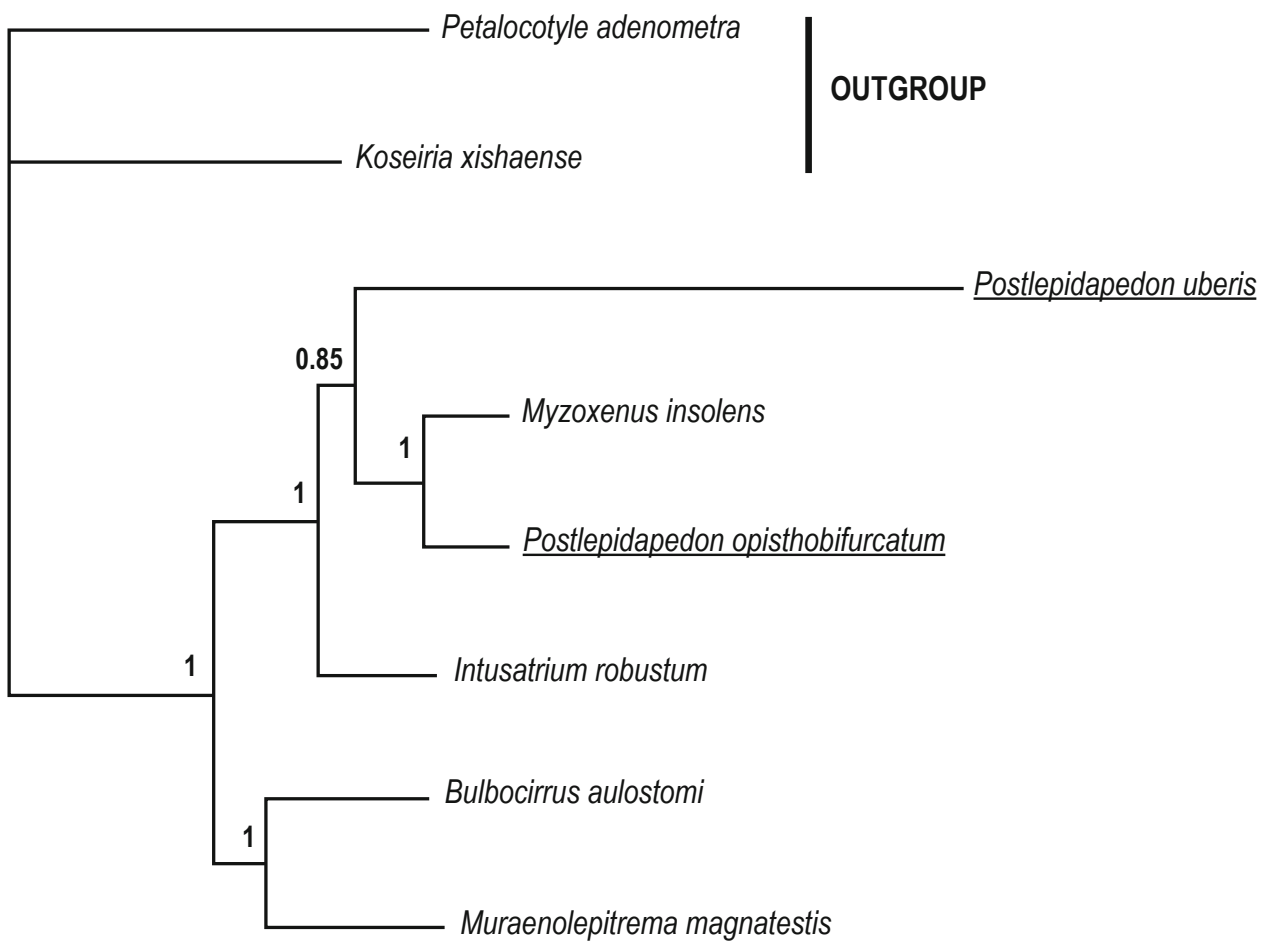

Fig. 2. Phylogenetic position of Postlepidapedon opisthobifurcatum within the Lepidapedidae based on $28 \mathrm{~S}$ rDNA sequences containing $900 \mathrm{bp}$ (a) and $1230 \mathrm{bp}$ (b) analysed by Bayesian inference; nodal numbers indicate posterior probabilities. Scale bar shows substitutions per site. 
only $P$. opisthobifurcatum among all the species currently recognised as representatives of genus Postlepidapedon will ultimately be proven to belong to this genus.

Phylogenetic analysis supports the position of $M$. insolens as the sister taxon of $P$. opisthobifurcatum. This result is unexpected because the indicated species are similar only by the signs common to many lepidapedids (see Bray \& Cribb, 1998, 2012; Bray, 2005). Definitive hosts of $P$. opisthobifurcatum are gadiform fishes, and for $M$. insolens - perciform fishes (Bray \& Cribb, 1998). Life cycles of these parasites are not known. In turn, $P$. opisthobifurcatum + $M$. insolens clade form a well-supported monophyletic group with the species I. robustum and $P$. uberis. In the phylogenetic model of Lepocreadioidea proposed by Bray et al. (2009) using partial 28S rDNA and nad1 sequences, this species group (without $P$. opisthobifurcatum) was named "clade III." Bray et al. (2009) noted the absence of a general morphological synapomorphy in representatives of the clade III (at least for adult specimens); therefore, taxonomic reorganisation or revision of this clade is premature.

\section{Conflict of Interest}

Authors state no conflict of interest.

\section{Acknowledgements}

The authors are grateful to the crew of $f / v$ Yantar-35 for their help in collecting the specimens. This study was supported by Russian Science Foundation \#17-74-10203.

\section{References}

BRAY, R.A. (2005): Family Lepocreadiidae Odhner, 1905. In: JONES, A., Bray, R.A., Gibson D.I. (Eds.) Keys to the Trematoda. Vol. 2. Wallingford, CABI Publishing and the Natural History Museum, pp. $545-602$

BrAY, R.A., CRIBB, T.H. (1998): Lepocreadiidae (Digenea) of Australian coastal fishes: new species of Opechona Looss, 1907, Lepotrema Ozaki, 1932 and Bianium Stunkard, 1930 and comments on other species reported for the first time or poorly known in Australian waters. Syst. Parasitol., 41: 123 - 148. DOI: 10.1023/A:1006055605808

BraY, R.A., CribB, T.H. (2001): Postlepidapedon quintum n. sp. (Digenea: Lepocreadiidae) from the bastard trumpeter Latridopsis forsteri (Perciformes: Latridae) off the coast of northern Tasmania. Pap. Proc. R. Soc. Tasmania, 135: 21 - 23

BRAY, R.A., CRIBB, T.H. (2012): Reorganization of the superfamily Lepocreadioidea Odhner, 1905 based on an inferred molecular phylogeny. Syst. Parasitol., 83: 169 - 177. DOI: 10.1007/s11230012-9386-3

Bray, R.A., CribB, T.H., Barker, S.C. (1997): Postlepidapedon Zdzitowiecki, 1993 and Gibsonivermis n. g. (Digenea: Lepocreadiidae) from fishes of the southern Great Barrier Reef, Australia, and their relationship to Intusatrium Durio \& Manter, 1968. Syst. Parasitol., 36: 143 - 155. DOI: 10.1023/A:1005729703302

Bray, R.A., Littlewood, D.T.J., Herniou, E.A., Williams, B., HenDERSON, R.E. (1999): Digenean parasites of deep-sea teleosts: a review and case studies of intrageneric phylogenies. Parasitol., 119: 125 - 144. DOI: 10.1017/S0031182000084687

Bray, R.A., Waeschenbach, A., Cribb, T.H., Weedall, G.D., Dyal, P., LITTLEWOod D.T.J. (2009): The phylogeny of the Lepocreadioidea (Platyhelminthes, Digenea) inferred from nuclear and mitochondrial genes: Implications for their systematics and evolution. Acta Parasitol., 54: 310 - 329. DOI: 10.2478/s11686-009-0045-z CRIBB, T.H. (2005): Family Opecoelidae Ozaki, 1925. In: Jones, A., Bray, R.A., GiBson D.I. (Eds) Keys to the Trematoda. Vol. 2. Wallingford, CABI Publishing and the Natural History Museum, pp. $443-531$

Gordeev, I.I., Sokolov, S.G. (2017): Helminths and the feeding habits of the marbled moray cod Muraenolepis marmorata Günther, 1880 (Gadiformes, Muraenolepididae) in the Ross Sea (Southern Ocean). Polar Biol., 40: 1311 - 1318. DOI. 10.1007/ s00300-016-2055-2

Huelsenbeck, J.P., Ronquist, F., Nielsen, R., Bollback, J.P. (2001): Bayesian inference of phylogeny and its impact on evolutionary biology. Science, 294: 2310 - 2314. DOI: 10.1126/science.1065889 Jeanmougin, F., Thompson, J.D., Gouy, M., Higgins, D.G., Gibson, T.J. (1998): Multiple sequence alignment with Clustal X. Trends Biochem. Sci., 23: 403 - 405

Kumar, S., Stecher, G., TAmuRA, K. (2016): MEGA7: Molecular evolutionary genetics analysis version 7.0 for bigger datasets. Mol. Biol. Evol., 33: 1870-1874. DOl:10.1093/molbev/msw054

MACHIDA, M. (2004): Four new species of digenean trematodes from wrasses of southern Japan and neighboring waters. Bul. Nat. Sci. Mus. Ser. A. Zool., 30: 105 - 111

Miller, M. A., Pfeiffer, W., Schwartz, T. (2010): Creating the CIPRES Science Gateway for inference of large phylogenetic trees. In: 2010 Gateway Computing Environments Workshop (GCE 2010). New Orleans, Louisiana, Institute of Electrical and Electronics Engineers, pp. 1-8.

Olson, P.D., Cribb, T.H., Tkach, V.V., Bray, R.A., Littlewood, D.T.J. (2003): Phylogeny and classification of the Digenea (Platyhelminthes: Trematoda). Int. J. Parasitol., 33: 733 - 755. DOI: 10.1016/S0020-7519(03)00049-3

Petrov, A.F., Shust, K.V., Pyanova, S.V., Uryupova, E.F., Gordeev, I.I., Sytov, A.M., Demina N.S. (2014): Guidelines for the collection and processing of fishing and biological data on aquatic bioresources of Antarctica for the Russian scientific observers in the CCAMLR convention area. Moscow: VNIRO Publishing, 103 pp. SHIMAZU, T. (2016): Digeneans Parasitic in Freshwater Fishes (Osteichthyes) of Japan. IX. Opecoelidae, Opecoelinae. Bull. Natl. Mus. Nat. Sci., Ser. A, 42: 163 - 180

Shimazu, T., Shimura, S. (1984): Paralepidapedon g. n. (Trematoda: Lepocreadiidae), with descriptions of metacercariae of Paralepidapedon hoplognathi (Yamaguti, 1938) comb. n. and of two other 
species from sea urchins. Zool. Sci., 1: $809-817$

Sokolov, S.G., GoRdeEv, I.I. (2013): New data on trematodes (Plathelminthes, Trematoda) of fishes in the Ross Sea (Antarctic). Invert. Zool., 10: 255 - 267

SoKolov, S.G., GoRdeEv, I.I. (2015): New data on trematodes of Antarctic fishes. Parazitologiya, 49: 12 - 27 (In Russian)

Tamura, K., Stecher, G., Peterson, D., Filipski, A., Kumar, S. (2013): MEGA6: Molecular Evolutionary Genetics Analysis version 6.0. Mol. Biol. Evol., 30: 2725 - 2729. DOl: 10.1093/molbev/mst197 TKach, V., Grabda-KazUbska, B., PaWlowski, J., SWiderski, Z. (1999): Molecular and morphological evidences for close phylogenetic affinities of the genera Macrodera, Leptophallus, Metaleptophallus and Paralepoderma (Digenea, Plagiorchioidea). Acta Parasitol., 44: $170-179$

TKach, V. V., LitTlewood, D. T. J., Olson, P. D., Kinsella, J. M., SwidERSKI, Z. (2003): Molecular phylogenetic analysis of the Microphal- loidea Ward, 1901 (Trematoda: Digenea). Syst. Parasitol., 56: 1 - 15. DOI: 10.1023/A:1025546001611

Walter, T., Palm, H. W., Piepiorka, S., Rückert, S. (2002): Parasites of the Antarctic rattail Macrourus whitsoni Regan, 1913 (Macrouridae, Gadiformes). Polar Biol., 25: 633 - 640. DOI: 10.1007/ s00300-002-0407-6

ZDZITOWIECKI, K. (1990): Little known and new Antarctic Digenea species of the genera Neolepidapedon and Lepidapedon (Lepocreadiidae). Acta Parasitol., 35: 19 - 30

ZDZITOWIECKI, K. (1993): A contribution to the morphology of the Antarctic fish lepocreadiid digeneans, with a description of a new genus. Acta Parasitol., 38: 109 - 112

ZDZITOWIECKI, K., CIELECKA, D. (1997): Digenea of fishes of the Weddell Sea. I. Parasites of Macrourus whitsoni (Gadiformes, Macrouridae). Acta Parasitol., 42: $23-30$ 